\title{
THERMAL EXPANSION OF MAGNESIUM AND SOME OF ITS ALLOYS
}

\author{
By Peter Hidnert and W. T. Sweeney
}

\section{ABSTRACT}

This paper gives data on the linear thermal expansion of 6 samples of cast and extruded magnesium and 11 samples of cast and extruded magnesium alloys (magnesium-aluminum and magnesium-aluminum-manganese alloys). The samples of magnesium were investigated over various temperature ranges between $-183^{\circ}$ and $+500^{\circ} \mathrm{C}$. and most of the alloys between room temperature and $300^{\circ} \mathrm{C}$.

Three types of apparatus were used in this research, and a summary of available data by previous observers on the thermal expansion of magnesium and some magnesium alloys is given.

The following average equation represents the expansion of magnesium between $20^{\circ}$ and $500^{\circ} \mathrm{C}$.:

$$
L_{\mathrm{t}}=L_{\mathrm{o}}\left[1+\left(24.80 t+0.00961 t^{2}\right) 10^{-6}\right]
$$

The coefficients of expansion of extruded magnesium and the alloys investigated are slightly less than those for the cast materials. A comparison of the average expansion curve obtained in the present investigation on magnesium, with data from previous observers, is shown graphically.

The relations between the chemical composition and the coefficients of expansion of the magnesium alloys are shown in a figure. The addition of 0 to 10 per cent aluminum to magnesium causes practically no change in the coefficients of expansion. Small additions of manganese (0.9 and 0.3 per cent) to magnesium and magnesium-aluminum alloys cause slight changes in the coefficients of expansion.

The table in the summary gives a comparison of the average coefficients of expansion of the materials investigated.

\section{CONTENTS}

Page

I. Introduction

II. Previous determinations _.

III. Materials investigated._._. 775

IV. Apparatus _.. 775

V. Results _...

1. Magnesium

2. Magnesium-aluminum alloys _._._. 782

3. Magnesium-aluminum-manganese alloys___._._._._._. 788

VI. Summary _._. 791 


\section{INTRODUCTION}

This paper gives the results of an investigation on the linear thermal expansion of pure magnesium, magnesium-aluminum alloys, and magnesium-aluminum-manganese alloys. Magnesium, the lightest structurally used metal, and its alloys are coming into greater prominence for materials of construction where low density and strength are important factors; for example, in aircraft manufacture and for moving parts of gasoline engines.

The earliest available observations on the thermal expansion of magnesium were those by Fizeau in 1869. However, up to the present time no data on the expansion of the alloys mentioned were available.

In the present investigation expansion determinations were made between $-183^{\circ}$ and $+500^{\circ} \mathrm{C}$. Six samples of cast and extruded magnesium were examined over various temperature ranges between $-183^{\circ}$ and $+500^{\circ} \mathrm{C}$. and 11 specimens of cast and extruded magnesium alloys between room temperature and $400^{\circ} \mathrm{C}$. The maximum aluminum content of the magnesium-aluminum alloys is 10.4 per cent, and the maximum aluminum content and maximum manganese content of the magnesium-aluminum-manganese alloys are 4.1 and 0.9 per cent, respectively.

The authors wish to express their appreciation for the cooperation by the American Magnesium Corporation, Niagara Falls, N. Y., and Aluminum Co. of America, New Kensington, Pa. The former furnished the samples of magnesium and magnesium alloys and information about the preparation, and the latter company analyzed the samples used in the investigation. Acknowledgment is due to H. W. Bearce, Wilmer Souder, and H. W. Gillett, of the Bureau of Standards, and J. D. Edwards, of the Aluminum Co. of America, for valuable suggestions.

\section{PREVIOUS DETERMINATIONS}

The results obtained by previous observers on the thermal expansion of magnesium and some magnesium alloys are summarized in Table 1. In this table, $a_{\mathrm{t}}$ represents the instantaneous coefficient or rate of expansion at $t^{\circ} \mathrm{C}$., $L_{\mathrm{t}}$ represents the length at $t^{\circ} \mathrm{C}$., and $L_{\mathrm{o}}$ the length at $0^{\circ} \mathrm{C}$. For additional information the reader should refer to the original papers. 
TABLE 1.-Summary of expansion data on magnesium and magnesium alloys by previous observers

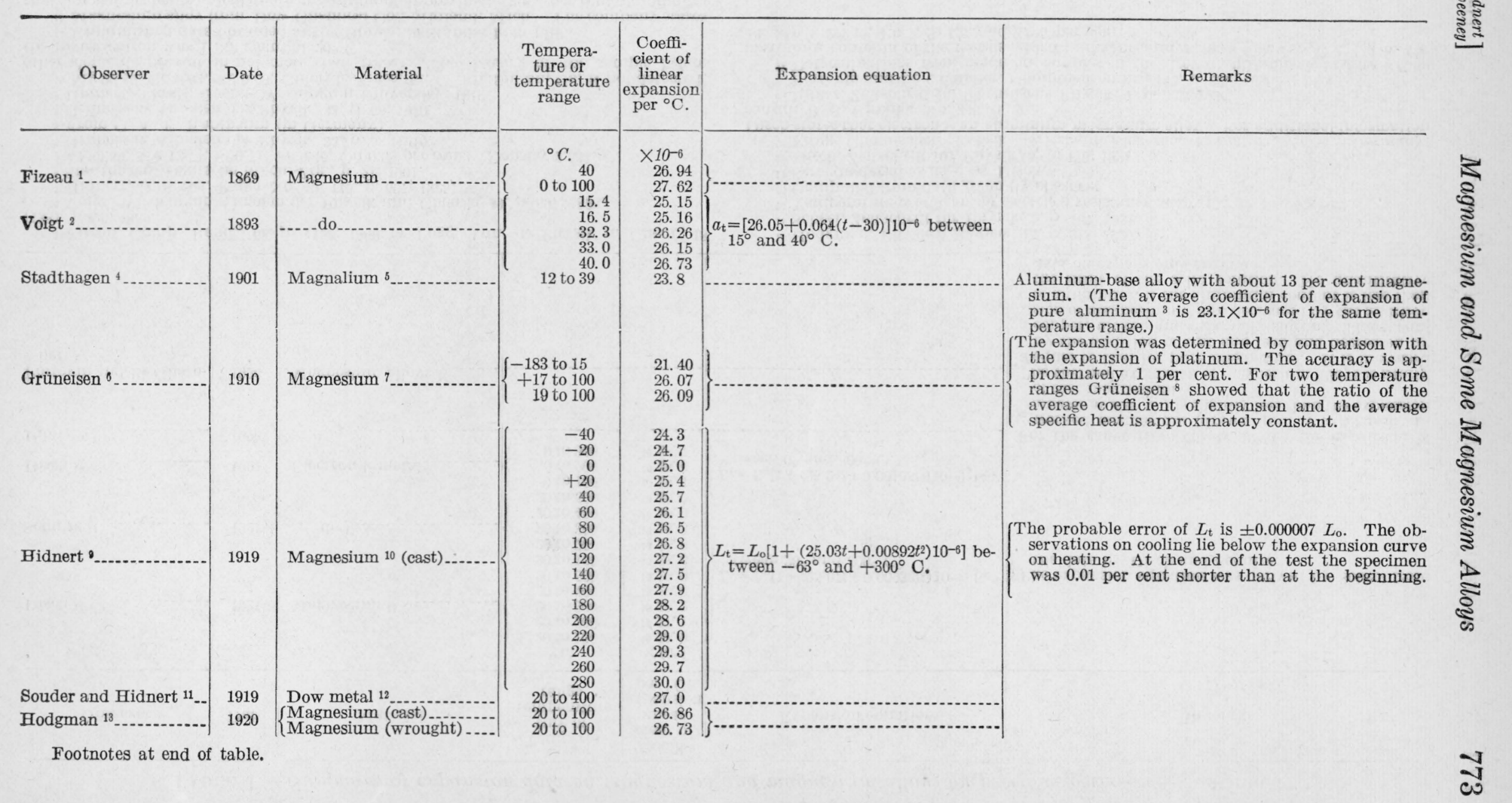


TABLE 1.-Summary of expansion data on magnesium and magnesium alloys by previous observers-Continued

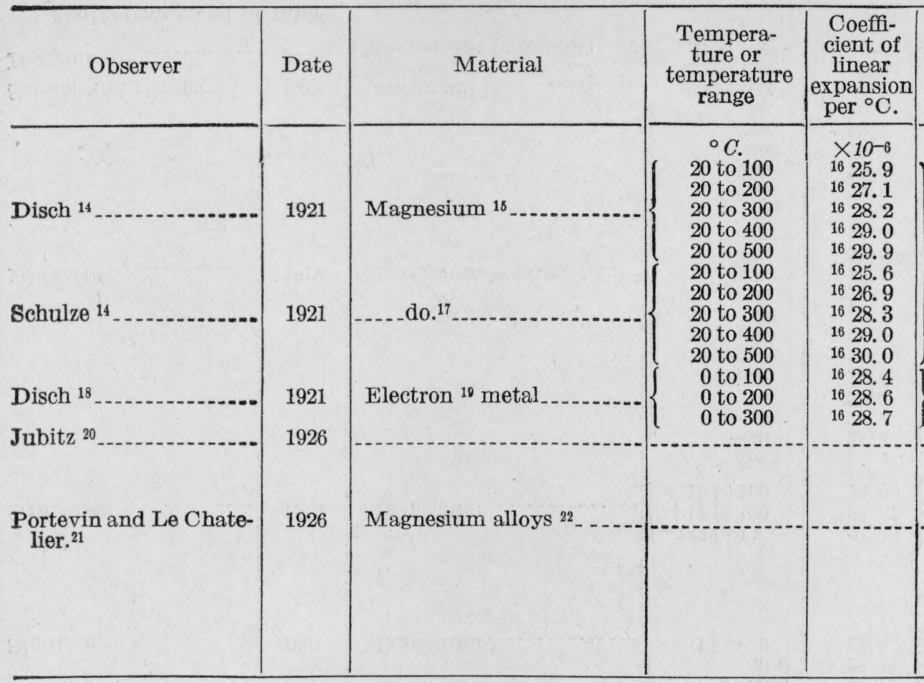

1 Fizeau, Comp. Rend., 68, p. 1125; 1869; or Pogg. Ann. d. Physik u. Chem., 18 (138), p. 26; 1869

Wiedemann Annalen der Physik und Chemie, 49, p. 697; 1893 ${ }^{3}$ Hidnert, B. S. Sci. Paper No. 497 (19, p. 697; 1925).

S Al 85.89, Mg 12.71, Si 0.71, Fe 0.46, Cu 0.08 per cent. Density 2.538

6 Grüneisen, Annalen der Physik, 33, p. 33; 1910 .

7 From C. A. F. Kahlbaum (in Germany)

${ }^{8}$ Grüneisen, Annalen der Physik, 33, p. 65; 1910.

Hidner, Thesis, George Washington University; 1919

, Si, C, $\mathrm{Pb}, \mathrm{Sn}, \mathrm{Zn}, \mathrm{Ca}, \mathrm{K}$ not detected other elements present in not more than traces. The density of the sample before

the investigation was $1.737 \mathrm{~g} / \mathrm{cm}^{3}$ at $20^{\circ} \mathrm{C}$.

12 Unpublished data obtained at the Bureau of Standards in 1919. that this sample had a calculated composition of approximately 8.5 per cent aluminum, with the balance magnesium.
Remarks

$L_{t}=L_{\mathrm{o}}\left[1+\left(25.07 t+0.00936 t^{2}\right) 10^{-6}\right]$ be tween $20^{\circ}$ and $500^{\circ} \mathrm{C}$.

$L_{t}=L_{\mathrm{o}}\left[1+\left(28.24 t+0.00165 t^{2}\right) 10^{-0}\right]$ between $0^{\circ}$ and $300^{\circ} \mathrm{C}$.

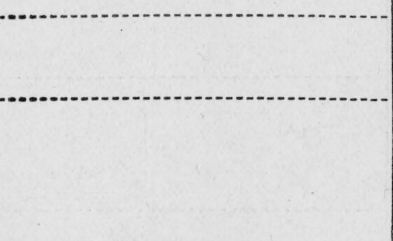

For the range from $20^{\circ}$ to $40^{\circ} \mathrm{C}$. the expansion of worked magnesium (drawn from 10 to $5.5 \mathrm{~mm}$. diameter at 200 C.) is slightly less than the expansion of cast magnesium.

The thermal expansion of magnesium alloys is nearly by the addition pure magnesium. It is increased copper, nickel, and especially silicon. The expansion of magnesium is also decreased by the addition of aluminum, if the aluminum content is less than the limit of the solid solution. No quantitative data on expansion were given.

${ }_{13}$ Hodgman, Physical Review, 15, p. 218; 1920.

Temperature coefficient of electrical resistance at $20^{\circ} \mathrm{C} ., 3.8$ to $3.9 \times 10^{-3}$.

${ }^{16}$ Computed from data given by observer.

17 Same material as used by Disch.

${ }_{18}$ Disch, Zeitschrift für Physik, 5, p. 173; 1921.

19 From Chemischen Fabrik Griesheim-Elektron, Frankfurt a. M., Germany. Disch states that electron is an aluminum-magnesium alloy. For additional information consult B. S. Circular No. 346, p. 302.

20 Jubitz, Zeitschrift für Technische Physik, 7, p. 522; 1926.

${ }^{22}$ Determinations were made on samples in the drawn and annealed state. The

maximum contents of the metals added to magn
$13, \mathrm{Mn} 4, \mathrm{Ni} 15, \mathrm{~Pb} 5$, Si 1.5, and $\mathrm{Zn} 5$ per cent. 
B. S. Journal of Research, RP29

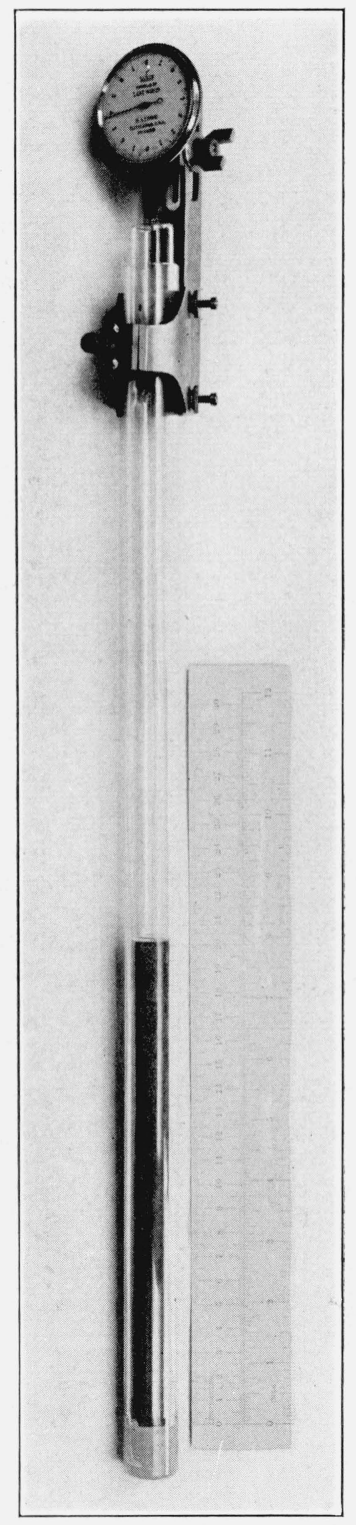

Fig. 1.-Fused quartz tube expansion apparatus 
B. S. Journal of Research, RP29

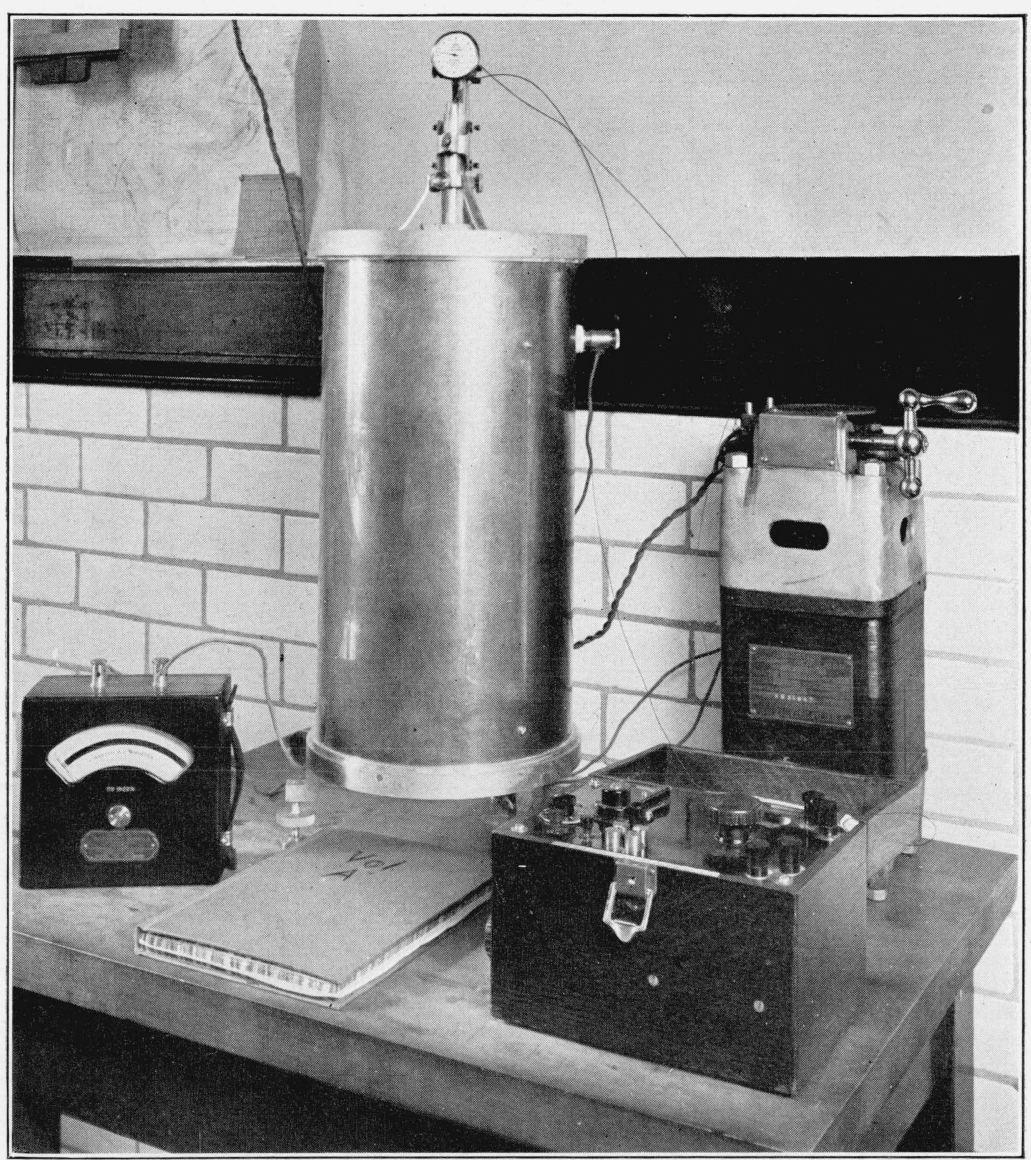

FIG. 2.-Fused quartz tube expansion apparatus and auxiliary equipment 


\section{MATERIALS INVESTIGATED}

The samples investigated are classified into three groups, as given in Table 2. This table also gives the chemical composition of the samples of magnesium and magnesium alloys.

The pure magnesium and the magnesium content of the alloys were of exceptional purity. The magnesium was made by the electrolysis of magnesium oxide dissolved in a fused fluoride bath and was subsequently purified by the sublimation process developed by H. E. Bakken, United States Patent 1594344, August 3, 1926.

TABLE 2.-Chemical composition of magnesium and magnesium alloys

\begin{tabular}{|c|c|c|c|c|c|c|c|c|}
\hline \multirow{2}{*}{ Material } & \multirow{2}{*}{ Sample } & \multicolumn{6}{|c|}{ Chemical analyses 1} & \multirow{2}{*}{ Treatment } \\
\hline & & $\begin{array}{l}\text { Magne- } \\
\text { sium }^{2}\end{array}$ & $\underset{\text { num }}{\text { Alumi- }}$ & $\begin{array}{c}\text { Manga- } \\
\text { nese }\end{array}$ & Silicon & Iron & Copper & \\
\hline \multirow{3}{*}{ Magnesium } & \multirow{3}{*}{$\begin{array}{l}1268 \mathrm{~A} \\
1269 \\
1269 \mathrm{I} \\
1269 \mathrm{~A}^{4} \\
1270 \\
1270 \mathrm{~A}^{5}\end{array}$} & $\begin{array}{l}\text { Per cent } \\
99.996\end{array}$ & $\begin{array}{c}\text { Per cent } \\
(3)\end{array}$ & $\begin{array}{c}\text { Per cent } \\
\left({ }^{3}\right)\end{array}$ & $\begin{array}{c}\text { Per cent } \\
0.002\end{array}$ & $\begin{array}{l}\text { Per cent } \\
<0.001\end{array}$ & $t\left|\begin{array}{l}\text { Per cent } \\
<0.001\end{array}\right|$ & Extruded at $410^{\circ} \mathrm{C}$. \\
\hline & & \}99. 99 & 0.00 & 0.00 & .000 & .005 & .002 & $\begin{array}{l}\text { Cast in vacuum furnace at } \\
665^{\circ} \mathrm{C} \text {. }\end{array}$ \\
\hline & & 99.97 & .02 & .00 & .004 & .007 & .002 & $\left\{\right.$ Extruded at $425^{\circ} \mathrm{C}$ \\
\hline \multirow{4}{*}{$\begin{array}{l}\text { Magnesium-alu- } \\
\text { minum alloys. }\end{array}$} & 1271 & $\begin{array}{l}95.61 \\
95.52\end{array}$ & $\begin{array}{l}4.36 \\
4.44\end{array}$ & .00 & .004 & .018 & .007 & $\begin{array}{l}\text { Extruded at } 350^{\circ} \mathrm{C} \text {. } \\
\text { Cast in vacuum furnace at } \\
680^{\circ} \mathrm{C} \text {. }\end{array}$ \\
\hline & $\begin{array}{l}1273 \\
1274\end{array}$ & $\begin{array}{l}93.70 \\
93.73\end{array}$ & $\begin{array}{l}6.26 \\
6.22\end{array}$ & .00 & $\begin{array}{l}.008 \\
.018\end{array}$ & $\begin{array}{l}.026 \\
.024\end{array}$ & $\begin{array}{l}.008 \\
.009\end{array}$ & $\begin{array}{l}\text { Extruded at } 330^{\circ} \mathrm{C} \text {. } \\
\text { Cast in vacuum furnace at } \\
680^{\circ} \mathrm{C} \text {. }\end{array}$ \\
\hline & $\left\{\begin{array}{l}1275 \\
1276\end{array}\right.$ & $\begin{array}{l}89.58 \\
89.75\end{array}$ & $\begin{array}{l}10.35 \\
10.19\end{array}$ & .00 & $\begin{array}{l}.016 \\
.014\end{array}$ & $\begin{array}{l}.040 \\
.034\end{array}$ & $\begin{array}{l}.016 \\
.008\end{array}$ & $\begin{array}{l}\text { Extruded at } 330^{\circ} \mathrm{C} \text {. } \\
\text { Cast in vacuum furnace at } \\
680^{\circ} \mathrm{C} \text {. }\end{array}$ \\
\hline & $\mid 1277$ & $\begin{array}{l}90.14 \\
89.84\end{array}$ & $\begin{array}{r}9.75 \\
10.04\end{array}$ & $\begin{array}{l}.00 \\
.00\end{array}$ & $\begin{array}{l}.068 \\
.076\end{array}$ & .033 & $\begin{array}{l}.012 \\
.010\end{array}$ & $\left\{\begin{array}{l}\text { Extruded at } 330^{\circ} \mathrm{C} \text {. held } \\
\text { at } 425^{\circ} \mathrm{C} \text {. for } 8 \text { hours, } \\
\text { quenched, and then aged } \\
\text { at } 175^{\circ} \mathrm{C} \text {. for } 72 \text { hours. }\end{array}\right.$ \\
\hline \multirow{2}{*}{$\begin{array}{l}\text { Magnesium - alu- } \\
\text { minum-manga- } \\
\text { nese alloys. }\end{array}$} & $\left\{\begin{array}{l}1278 \\
1279\end{array}\right.$ & $\begin{array}{l}95.58 \\
95.53\end{array}$ & $\begin{array}{l}\text { 4. } 10 \\
\text { 4. } 14\end{array}$ & .27 & .014 & $\begin{array}{l}.025 \\
.029\end{array}$ & $\begin{array}{l}.011 \\
.009\end{array}$ & $\begin{array}{l}\text { Extruded at } 390^{\circ} \mathrm{C} \text {. } \\
\text { Cast in vacuum furnace at } \\
690^{\circ} \mathrm{C} \text {. }\end{array}$ \\
\hline & 1280 & 99.05 & .01 & .91 & .004 & .020 & .003 & Cast at $670^{\circ} \mathrm{C}$. \\
\hline
\end{tabular}

1 The analysis on sample $1268 \mathrm{~A}$ was made by J. P. Hancock, of this bureau, and the analyses on the other samples were made by the technical direction bureau, Aluminum Co. of America.

2 Per cent magnesium determined by difference.

Not detected.

4 Duplicate of sample 1269.

5 Duplicate of sample 1270 .

\section{APPARATUS}

Three types of equipment were used in this research, namely: (a) Precision comparator; ${ }^{1}$ (b) interferometer; ${ }^{2}$ (c) fused-quartz tube.

Types $(a)$ and $(b)$ are described in previous bureau publications. A short description of $(c)$ follows:

A fused-quartz-tube apparatus was used in some determinations of the expansion of magnesium between $-183^{\circ}$ and $+20^{\circ} \mathrm{C}$. The authors have improved this type of apparatus from a similar type

1 Souder and Hidnert, B. S. Sci. Paper No. 524 (21, p. 1; 1926).

2 Peters and Cragoe, B. S. Sci. Paper No. 393 (16, p. 449; 1920). 
used abroad and recommend this type for commercial laboratories where data of the highest precision are not necessary. With this equipment, which has been used for various temperature ranges between $-183^{\circ}$ and $+1,000^{\circ} \mathrm{C}$., it is possible to obtain an accuracy of better than 2 per cent. A short description of the equipment appeared in Technical News Bulletin of the Bureau of Standards No. 123, page $2 ; 1927$.

Figure 1 shows a fused-quartz tube closed at one end, with a sample $(20 \mathrm{~cm})$ in place ready for heating or cooling. A movable

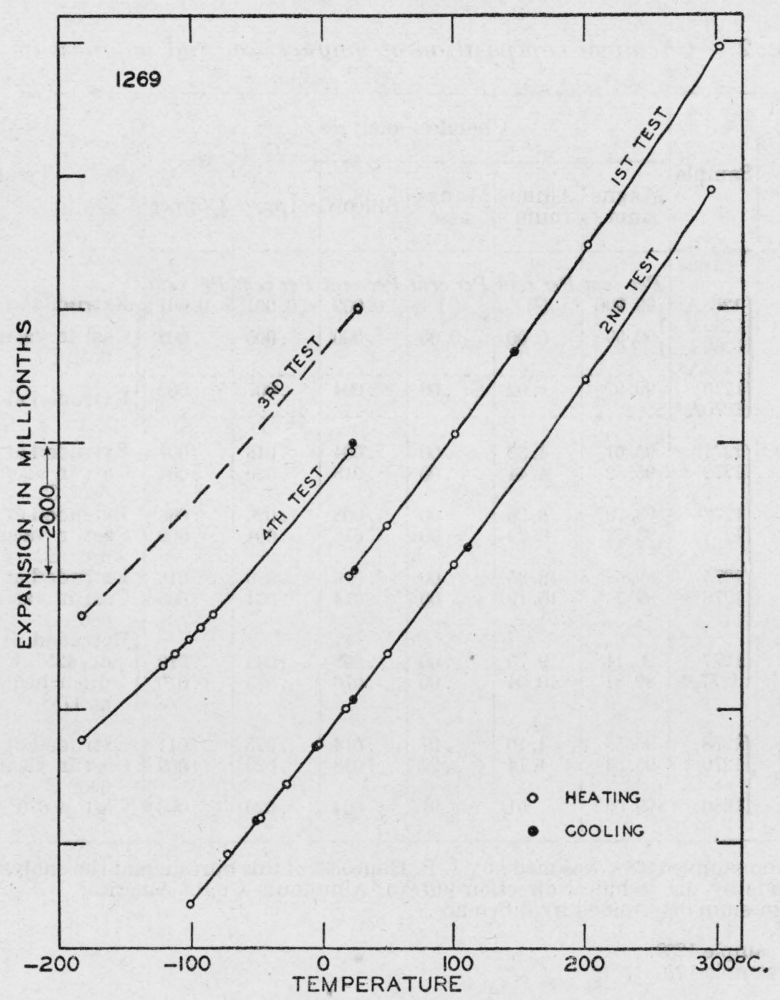

Fig. 3.-Linear thermal expansion of cast magnesium (99.99 per cent) from $-183^{\circ}$ to $+300^{\circ} \mathrm{C}$.

fused-quartz rod rests on top of the sample and extends above the open end of the tube. The bottoms of the tube and the movable rod are ground concave and the ends of the sample convex in order to secure satisfactory contacts. The top of the movable rod, on which an indicator gauge rests, is flat. Heating is effected by placing the tube containing the sample in a water or oil bath or electrical furnace (fig. 2) extending well above the top of the sample. Low temperatures are secured by using proper cooling baths. In the 
present investigation liquid oxygen was used. A thermocouple placed inside the fused-quartz tube near the center of the sample indicates the temperature. An indicator gauge fastened near the top of the tube registers the differential expansion between the sample and an equivalent length $(20 \mathrm{~cm})$ of fused quartz. A small correction for the expansion ${ }^{3}$ of fused quartz is made.

Figures 1 and 2 show the fused-quartz-tube apparatus and auxiliary equipment.

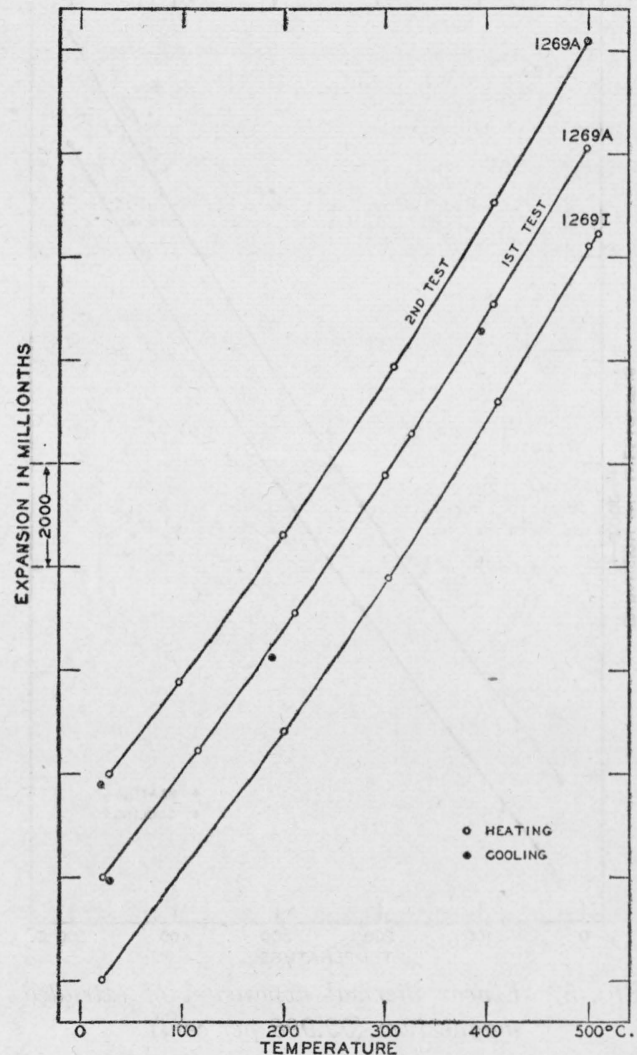

FIG. 4.-Linear thermal expansion of cast magnesium (99.99 per cent) from $20^{\circ}$ to $500^{\circ} \mathrm{C}$.

\section{RESULTS}

The results obtained on magnesium, magnesium-aluminum alloys, and magnesium-aluminum-manganese alloys are given in the following subsections. The expansion curves of all samples investigated are shown in figures. In all cases the coefficients of expansion were derived from the observations on heating.

\footnotetext{
${ }^{3}$ Souder and Hidnert, B. S. Sci. Paper No. 524 (21, p. 1; 1926).
} 


\section{MAGNESIUM}

The linear thermal expansion of six samples of magnesium containing about 99.99 per cent magnesium were investigated over various temperature ranges between $-183^{\circ}$ and $+500^{\circ} \mathrm{C}$. Since preliminary work on small pieces of magnesium showed that this metal oxidized in air at about $550^{\circ} \mathrm{C}$., the maximum temperature of the expansion tests did not exceed this temperature.

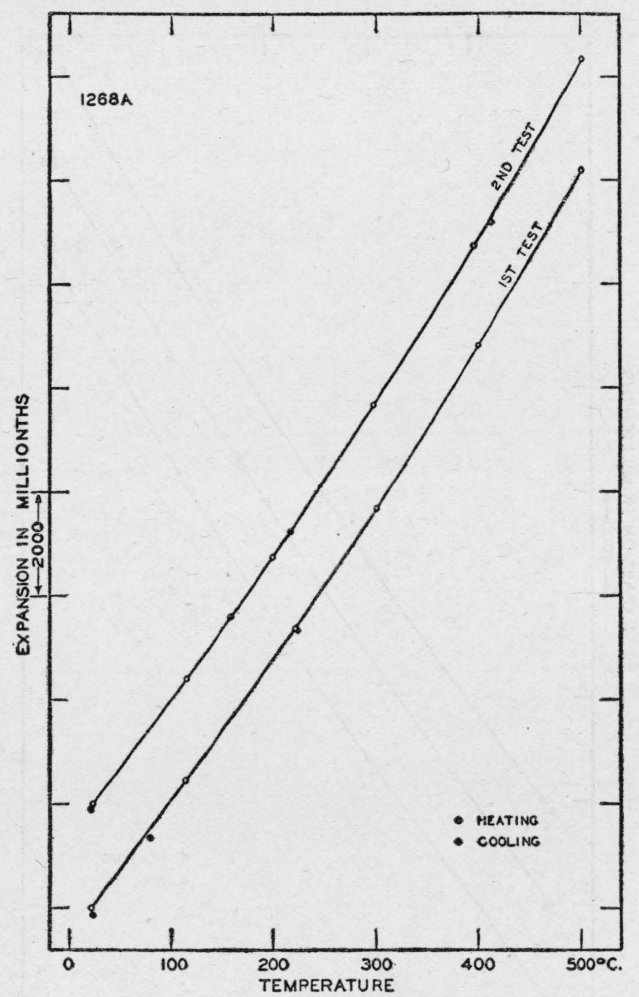

FIG. 5.-Linear thermal expansion of extruded magnesium (99.996 per cent)

The results obtained on cast and extruded magnesium are shown in Figures 3 to 7 , inclusive. The coefficients of expansion which were derived from the expansion curves are given in Table 3 . The last column in this table shows the differences in length before and after the expansion tests. The plus $(+)$ sign indicates an increase in length and the minus (-) sign a decrease in length. 


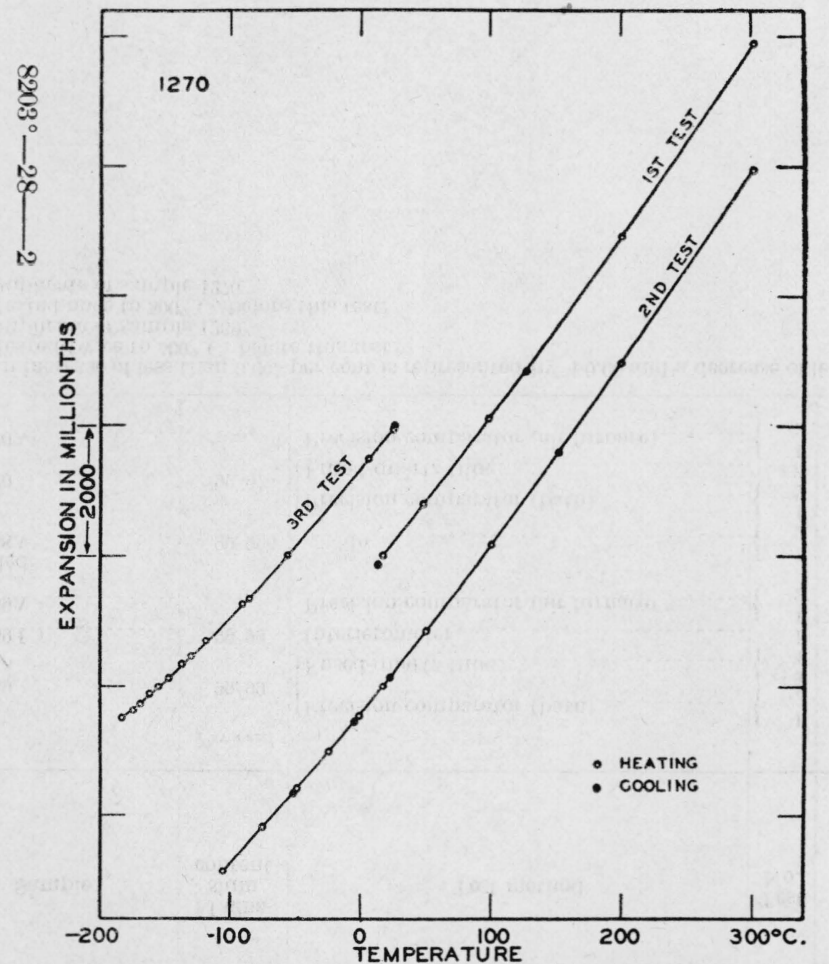

FIG. 6.-Linear thermal expansion of extruded mag nesium $\left(99.97\right.$ per cent) from $-183^{\circ}$ to $+300^{\circ} \mathrm{C}$.

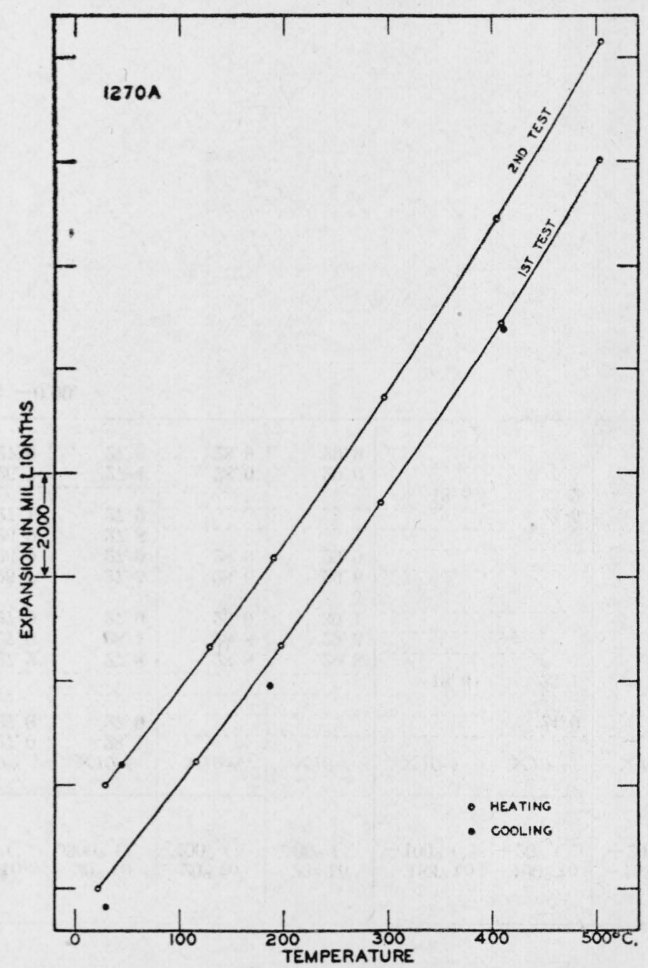

Fig. 7.-Linear thermal expansion of extruded magnesium $\left(99.97\right.$ per cent) from $20^{\circ}$ to $500^{\circ} \mathrm{C}$. 
TABLE 3.-Average coefficients of expansion and length changes of magnesium

\begin{tabular}{|c|c|c|c|c|c|c|c|c|c|c|c|c|}
\hline \multirow[b]{2}{*}{ Sample } & \multirow{2}{*}{$\begin{array}{l}\text { Magne- } \\
\text { sium } \\
\text { content }\end{array}$} & \multirow[b]{2}{*}{ Test method } & \multirow[b]{2}{*}{$\begin{array}{l}\text { Test } \\
\text { No. }\end{array}$} & \multicolumn{8}{|c|}{ A verage coefficients of expansion per ${ }^{\circ} \mathrm{C}$. } & \multirow{2}{*}{$\begin{array}{l}\text { Change } 1 \\
\text { in length } \\
\text { due to } \\
\text { heat } \\
\text { treatment } \\
\text { received } \\
\text { during } \\
\text { test }\end{array}$} \\
\hline & & & & $\begin{array}{l}20^{\circ} \text { to } \\
100^{\circ} \mathrm{C}\end{array}$ & $\begin{array}{l}20^{\circ} \text { to } \\
200^{\circ} \mathrm{C}\end{array}$ & $\begin{array}{r}20^{\circ} \text { to } \\
300^{\circ} \mathrm{C} .\end{array}$ & $\begin{array}{l}20^{\circ} \text { to } \\
400^{\circ} \mathrm{C}\end{array}$ & $\begin{array}{l}20^{\circ} \text { to } \\
500^{\circ} \mathrm{C}\end{array}$ & $\begin{array}{l}-183^{\circ} \text { to } \\
-100^{\circ} \mathrm{C} .\end{array}$ & $\begin{array}{l}-100^{\circ} \text { to } \\
+20^{\circ} \mathrm{C} .\end{array}$ & $\begin{array}{l}-183^{\circ} \text { to } \\
+20^{\circ} \mathrm{C} .\end{array}$ & \\
\hline $\begin{array}{l}\text { Cast: } \\
\quad 1269 .\end{array}$ & $\begin{array}{c}\text { Per cent } \\
\quad 99.99\end{array}$ & $\left\{\begin{array}{l}\text { Precision comparator (bath) } \\
\text { Fused-quartz tube }\end{array}\right.$ & $\left\{\begin{array}{r}1 \\
2 \\
23 \\
4\end{array}\right.$ & $\begin{array}{r}\times 10^{-6} \\
26.1 \\
26.0 \\
\end{array}$ & $\begin{array}{r}\times 10^{-6} \\
27.0 \\
\quad 27.0\end{array}$ & $\begin{array}{r}\times 10^{-6} \\
28.1 \\
27.9\end{array}$ & $\times 10^{-6}$ & $\times 10^{-6}$ & $\times 10^{-6}$ & $\times 10^{-6}$ & \begin{tabular}{r}
$\times 10^{-6}$ \\
\hdashline 21.9 \\
21.2
\end{tabular} & $\begin{array}{r}\text { Per cent } \\
0.00 \\
.00 \\
.00 \\
-.01\end{array}$ \\
\hline $1269 \mathrm{I}$ & 99.99 & $\begin{array}{l}\text { Interferometer } \\
\text { Precision comparator (air furnace) }\end{array}$ & $\left\{\begin{array}{l}4 \\
1 \\
1 \\
2\end{array}\right.$ & $\begin{array}{l}26.6 \\
26.0\end{array}$ & $\begin{array}{l}27.2 \\
27.0 \\
27.0\end{array}$ & $\begin{array}{l}27.8 \\
28.1 \\
27.9\end{array}$ & $\begin{array}{l}28.8 \\
28.8 \\
29.0\end{array}$ & $\begin{array}{l}29.8 \\
29.6 \\
30.1\end{array}$ & \begin{tabular}{|c|} 
\\
\hdashline
\end{tabular} & & & $\begin{array}{l}-.02 \\
+.00\end{array}$ \\
\hline $\begin{array}{r}\text { Extruded: } \\
1268 \mathrm{~A} \\
1270\end{array}$ & $\begin{array}{l}99.996 \\
99.97\end{array}$ & Precision comparator (bath) & $\left\{\begin{array}{l}1 \\
2 \\
1 \\
2\end{array}\right.$ & $\begin{array}{l}26.4 \\
26.2 \\
26.0 \\
26.0\end{array}$ & $\begin{array}{l}26.7 \\
26.9 \\
26.9 \\
27.1\end{array}$ & $\begin{array}{l}27.5 \\
27.9 \\
27.8 \\
27.9\end{array}$ & $\begin{array}{l}28.6 \\
28.9\end{array}$ & $\begin{array}{l}29.6 \\
29.9\end{array}$ & - & r23. 5 & 3 & $\begin{array}{l}-.01 \\
=.00 \\
-.00 \\
-.00 \\
-.00\end{array}$ \\
\hline $1270 \mathrm{~A}^{5}$ & & Precision comparator (air furnace) & $\left\{\begin{array}{l}0 \\
2 \\
2\end{array}\right.$ & $\begin{array}{l}26.3 \\
26.4\end{array}$ & 26.7 & $\begin{array}{l}27.4 \\
27.8\end{array}$ & $\begin{array}{l}28.0 \\
28.9\end{array}$ & $\begin{array}{r}29.0 \\
29.9\end{array}$ & & & & $\begin{array}{r}-.06 \\
.00\end{array}$ \\
\hline
\end{tabular}

1 An increase of less than 0.005 per cent is represented by +0.00 and a decrease of less than 0.005 by -0.00 .

2 Heated twice to $500^{\circ} \mathrm{C}$. before this test.

Duplicate of sample 1269 .

${ }_{5}$ Heated once to $500^{\circ} \mathrm{C}$. before this test. 
Table 4 gives expansion equations for samples 1269, 1269 I, 1269A, and 1268A. These equations were derived, by the method of least squares, from the observations on heating. $\Delta L$ represents the expansion or change in length from $20^{\circ} \mathrm{C}$. to any temperature $t$ between $20^{\circ}$ and $500^{\circ}$ C., $L_{\mathrm{t}}$ represents the length of the metal at any temperature $t$ between $20^{\circ}$ and $500^{\circ} \mathrm{C}$., and $L_{0}$ the length at $0^{\circ} \mathrm{C}$.

TABLE 4.-Expansion equations of magnesium

\begin{tabular}{|c|c|c|c|}
\hline Sample & $\begin{array}{l}\text { Test } \\
\text { No. }\end{array}$ & Expansion equations & $\begin{array}{l}\text { Probable } \\
\text { error of } \\
\Delta L \text { or } L_{t}\end{array}$ \\
\hline $\begin{array}{l}\text { Cast: } \\
1269 \\
1269 \mathrm{I}- \\
1269 \mathrm{~A} .\end{array}$ & 1 & $\left\{\begin{array}{l}\Delta L=25.50(t-20) 10^{-6}+0.00871(t-20)^{2} 10^{-6} \\
L_{\mathrm{t}}=L_{\mathrm{o}}\left[1+\left(25.15 t+0.00871 t^{2}\right) 10^{-6}\right]\end{array}\right\}$ & $\begin{aligned} & \times L_{\mathrm{o}} \\
\pm & 0.000022\end{aligned}$ \\
\hline 1269 & 2 & $\left\{\begin{array}{l}\Delta L=25.15(t-20) 10^{-6}+0.01021(t-20)^{2} 10^{-6} \\
L_{t}=L_{0}\left[1+\left(24.74 t+0.01021 t^{2}\right) 10^{-6}\right]\end{array}\right\}$ & \pm .000007 \\
\hline $\begin{array}{l}\text { Extruded: } \\
\text { 1268A }\end{array}$ & 1 & $\left\{\begin{array}{l}\Delta L=24.85(t-20) 10^{-6}+0.00982(t-20)^{2} 10^{-6} \\
L_{t}=L_{\circ}\left[1+\left(24.46 t+0.00982 t^{2}\right) 10^{-6}\right]\end{array}\right\}$ & \pm .000025 \\
\hline $1268 \mathrm{~A}$. & 2 & $\left\{\begin{array}{l}\Delta L=25.26(t-20) 10^{-0}+0.00971(t-20)^{2} 10^{-6} \\
L_{\mathrm{t}}=L_{\mathrm{o}}\left[1+\left(24.87 t+0.00971 t^{2}\right) 10^{-6}\right]\end{array}\right\}$ & \pm .000016 \\
\hline
\end{tabular}

The following average equations may be given as the most probable second-degree equations for the expansion of cast magnesium and extruded magnesium between room temperature and $500^{\circ} \mathrm{C}$.:

Cast magnesium:

$$
L_{\mathrm{t}}=L_{\mathrm{o}}\left[1+\left(24.94 t+0.00946 t^{2}\right) 10^{-6}\right]
$$

Extruded magnesium:

$$
L_{\mathrm{t}}=L_{\mathrm{o}}\left[1+\left(24.66 t+0.00976 t^{2}\right) 10^{-6}\right]
$$

Average of equations (1) and (2):

$$
L_{\mathrm{t}}=L_{\mathrm{o}}\left[1+\left(24.80 t+0.00961 t^{2}\right) 10^{-6}\right]
$$

The average coefficients of expansion for various temperature

\begin{tabular}{|c|c|c|c|}
\hline \multirow{2}{*}{ Temperature range (in ${ }^{\circ} \mathrm{C}$. ) } & \multicolumn{3}{|c|}{$\begin{array}{l}\text { Average coefficient of expansion } \\
\text { per }{ }^{\circ} \mathrm{C} \text {. }\end{array}$} \\
\hline & $\begin{array}{c}\text { Cast } \\
\text { magnesium }\end{array}$ & $\begin{array}{c}\text { Extruded } \\
\text { magnesium }\end{array}$ & A verage \\
\hline $\begin{array}{l}20 \text { to } 100 \\
100 \text { to } 2000 \\
200 \text { to } 300 \\
300 \text { to } 400 \\
400 \text { to } 500\end{array}$ & $\begin{array}{r}\times 10^{-6} \\
26.1 \\
27.8 \\
29.7 \\
31.6 \\
33.5\end{array}$ & $\begin{array}{r}\times 10^{-6} \\
25.8 \\
27.6 \\
29.5 \\
31.5 \\
33.4\end{array}$ & $\begin{array}{r}\times 10-6 \\
26.0 \\
27.7 \\
29.6 \\
31.5 \\
33.4\end{array}$ \\
\hline $\begin{array}{l}20 \text { to } 200 \\
20 \text { to } 300 \\
20 \text { to } 400 \\
20 \text { to } 500\end{array}$ & $\begin{array}{l}27.0 \\
28.0 \\
28.9 \\
29.9\end{array}$ & $\begin{array}{l}26.8 \\
27.8 \\
28.8 \\
29.7\end{array}$ & $\begin{array}{l}26.9 \\
27.9 \\
28.8 \\
29.8\end{array}$ \\
\hline
\end{tabular}
ranges given in Table 5 were computed from equations (1), (2), and (3).

TABLE 5.-Average coefficients of expansion of magnesium 
The coefficients of expansion of extruded magnesium are slightly less than those for cast magnesium. Jubitz ${ }^{4}$ also found that worked magnesium expands slightly less than cast magnesium. The largest variation in the coefficients given in Table 5 is $0.3 \times 10^{-6}$.

The instantaneous coefficients or rates of expansion of cast magnesium and extruded magnesium from $0^{\circ}$ to $500^{\circ} \mathrm{C}$. are shown in Figure 8. The coefficients increase with temperature. The greatest variation $\left(0.3 \times 10^{-6}\right)$ in the rates of expansion of the cast and extruded metal occurs at $0^{\circ} \mathrm{C}$. Above this temperature the variation decreases with temperature.

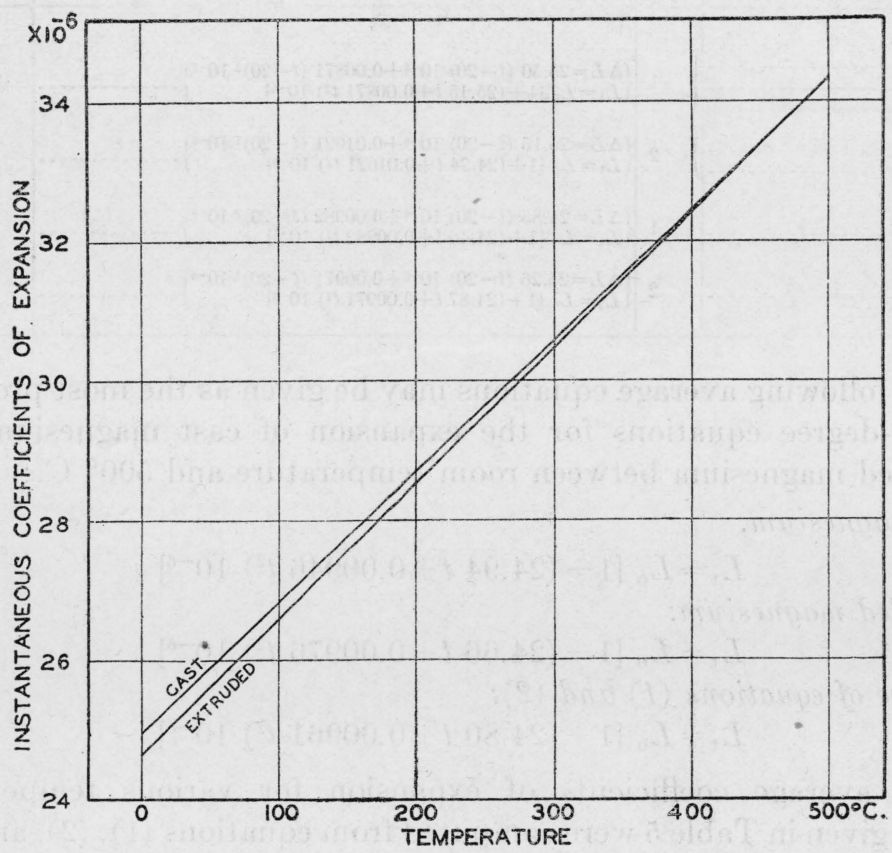

Frg. 8.-Instantaneous coefficients of expansion of magnesium

Figure 9 shows a comparison of the average expansion curve obtained in the present investigation on magnesium, with data from previous observers. The curve was derived from equation (3) and the data at low temperatures. The values of nearly all observers show good agreement.

\section{MAGNESIUM-ALUMINUM ALLOYS}

Eight samples of magnesium-aluminum alloys containing various percentages of aluminum ( 4 to 10 per cent) were investigated. Al samples except $1277 \mathrm{~A}$ were investigated by the precision-comparator

See Table 1, p. 773. 
method (bath) from room temperature to $300^{\circ} \mathrm{C}$. The interference method was used for sample $1277 \mathrm{~A}$ from room temperature to $400^{\circ} \mathrm{C}$.

Figures 10 to 13 , inclusive, show the observations obtained on the magnesium-aluminum alloys. The expansion curves of all samples except 1277 and $1277 \mathrm{~A}$ are regular. The curves for samples 1277 and $1277 \mathrm{~A}$ which received special heat treatment, ${ }^{5}$ show critical regions above $200^{\circ} \mathrm{C}$.

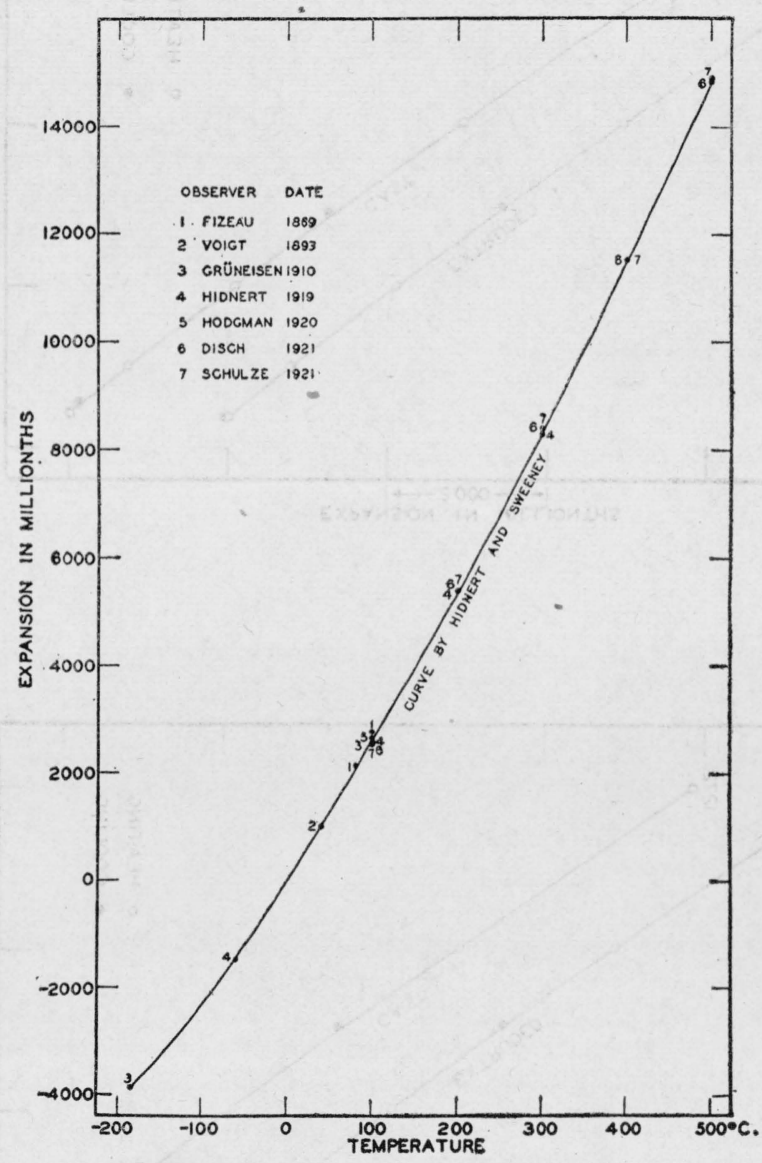

Fig. 9.-Comparison of the average expansion curve obtained in the present investigation on magnesium with data from previous observers

The average coefficients of expansion given in Table 6 were derived from the expansion curves of the magnesium-aluminum alloys. This table also indicates the differences in length before and after the expansion tests. The plus $(+)$ sign signifies an increase in length and the minus $(-)$ sign a decrease in length.

\footnotetext{
${ }^{\circ}$ Extruded at $330^{\circ} \mathrm{C}$, held at $425^{\circ} \mathrm{C}$, for 8 hours and quenched, and then aged at $175^{\circ} \mathrm{C}$. for 72 hours.
} 


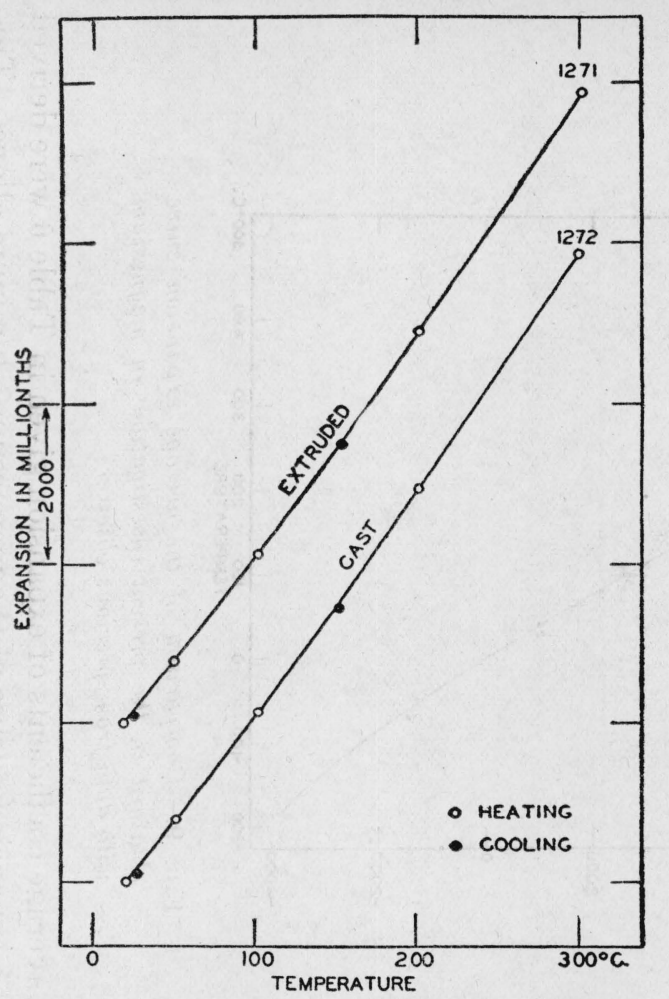

Fig. 10.-Linear thermal expansion of magnesium-aluminum alloys (4 per cent aluminum)

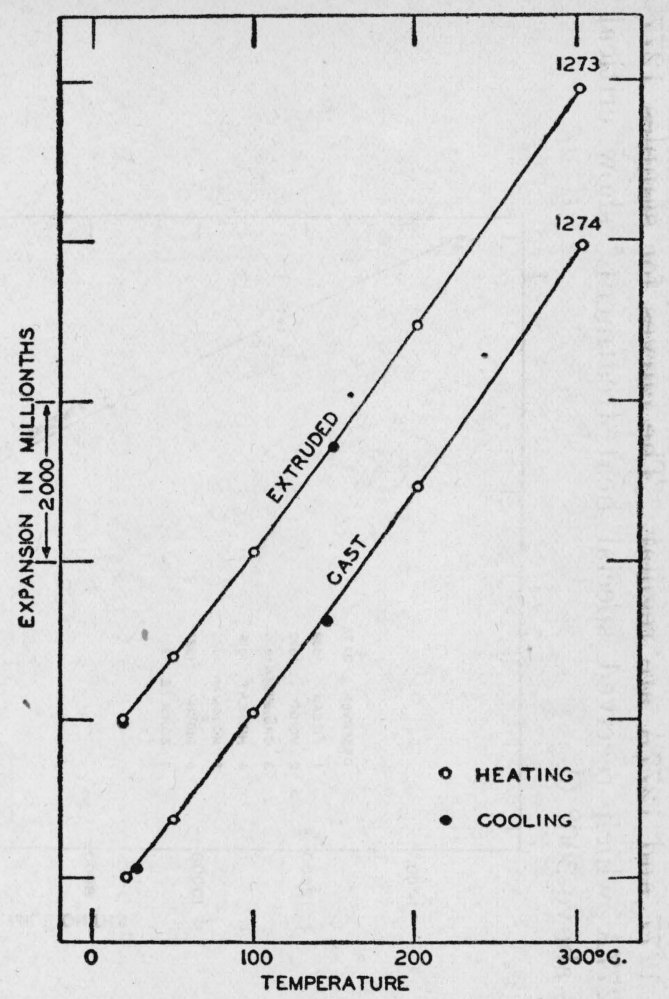

ڤ

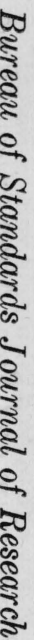

FIg. 11.-Linear thermal expansion of magnesium-aluminum alloys (6 per cent aluminum) 


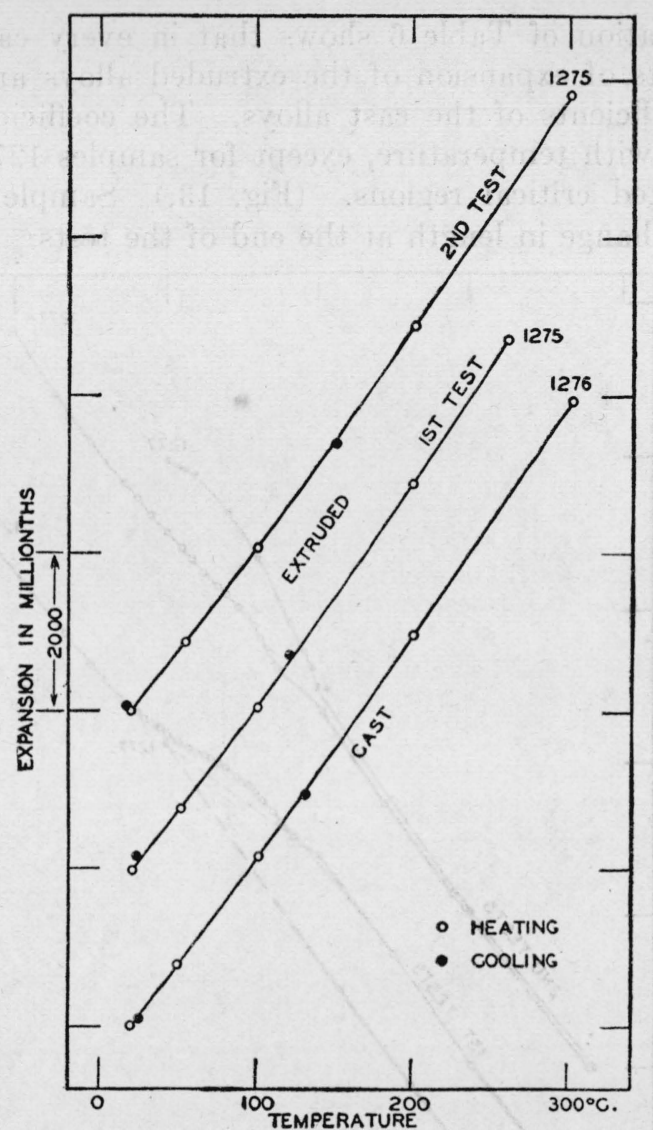

Frg. 12.-Linear thermal expansion of magnesium-aluminum alloys (10 per cent aluminum)

TABLE 6.-Average coefficients of expansion and length changes of magnesium aluminum alloys

\begin{tabular}{|c|c|c|c|c|c|c|c|c|c|}
\hline \multirow[b]{2}{*}{ Sample } & \multirow[b]{2}{*}{$\begin{array}{l}\text { Alumi- } \\
\text { num } \\
\text { con- } \\
\text { tent }\end{array}$} & \multirow[b]{2}{*}{ Treatment } & \multicolumn{6}{|c|}{ A verage coefficients of expansion per ${ }^{\circ} \mathrm{C}$. } & \multirow{2}{*}{$\begin{array}{l}\text { Change } \\
\text { in length } \\
\text { due to } \\
\text { heat } \\
\text { treat- } \\
\text { ment } \\
\text { received } \\
\text { during } \\
\text { test }\end{array}$} \\
\hline & & & $\begin{array}{c}20^{\circ} \text { to } \\
50^{\circ} \\
\text { C. }\end{array}$ & $\begin{array}{c}20^{\circ} \text { to } \\
100^{\circ} \\
\mathrm{C} .\end{array}$ & $\begin{array}{c}20^{\circ} \text { to } \\
200^{\circ} \\
\mathrm{C} .\end{array}$ & $\begin{array}{c}20^{\circ} \text { to } \\
300^{\circ} \\
\mathrm{C} .\end{array}$ & $\begin{array}{c}200^{\circ} \\
\text { to } \\
300^{\circ} \\
\text { C. }\end{array}$ & $\begin{array}{c}300^{\circ} \\
\text { to } \\
400^{\circ} \\
\text { C. }\end{array}$ & \\
\hline & Perct. & & $\times 10^{-6}$ & $\times 10^{-6}$ & $\times 10^{-6}$ & $\times 10^{-6}$ & $\times 10^{-0}$ & $\times 10^{-6}$ & Per ct. \\
\hline 72 & $\begin{array}{l}4.44 \\
4.36\end{array}$ & Extru & 25. & & & & & & $\begin{array}{l}-0.01 \\
-.01\end{array}-1$ \\
\hline & 6.22 & Cast in vacuum furnace at $680^{\circ} \mathrm{C}$ & 25. & 26. & 27 & 28 & & & -.00 \\
\hline & 6.26 & Extruded at $330^{\circ} \mathrm{C}$ & 26.0 & 26.2 & 27.1 & 27.9 & & & -.00 \\
\hline 1277 & 9.75 & $\left\{\begin{array}{r}\text { Extruded at } 330^{\circ} \text { C., held at } 425^{\circ} \\
\mathrm{C} \text {. for } 8 \text { hours, quenched, and } \\
\text { then aged at } 175^{\circ} \mathrm{C} \text {. for } 72 \text { hours. }\end{array}\right.$ & 25.3 & $\begin{array}{r}25.4 \\
125.7\end{array}$ & $\begin{array}{l}26.5 \\
27.8\end{array}$ & & $\begin{array}{l}14.4 \\
29.8\end{array}$ & & $\begin{array}{l}-.14 \\
+.04\end{array}$ \\
\hline $1277 \mathrm{~A}$ & 10.04 & Same as 1277 & $-\cdot$ & $\begin{array}{r}26.0 \\
125.8\end{array}$ & $\begin{array}{l}26.1 \\
26.9\end{array}$ & & $\begin{array}{l}17.0 \\
22.6\end{array}$ & 21.7 & $-2.0-2$ \\
\hline 1276. & 10.19 & Cast in vacuum furnace at $680^{\circ} \mathrm{C}$. & 25.3 & 26.2 & 27.3 & 28 & & & -.00 \\
\hline 1275 & 10.35 & Extruded at $330^{\circ} \mathrm{C}$ & $\left\{\begin{array}{r}24.9 \\
124.7\end{array}\right.$ & $\begin{array}{l}25.9 \\
25.6\end{array}$ & $\begin{array}{l}27.2 \\
26.9\end{array}$ & $\begin{array}{r}228.3 \\
27.7\end{array}$ & & & $\begin{array}{l}+.01 \\
+.01\end{array}$ \\
\hline
\end{tabular}


An examination of Table 6 shows that in every case except one the coefficients of expansion of the extruded alloys are slightly less than the coefficients of the cast alloys. The coefficients of expansion increase with temperature, except for samples 1277 and $1277 \mathrm{~A}$, which indicated critical regions. (Fig. 13.) Sample 1277 showed the greatest change in length at the end of the tests.

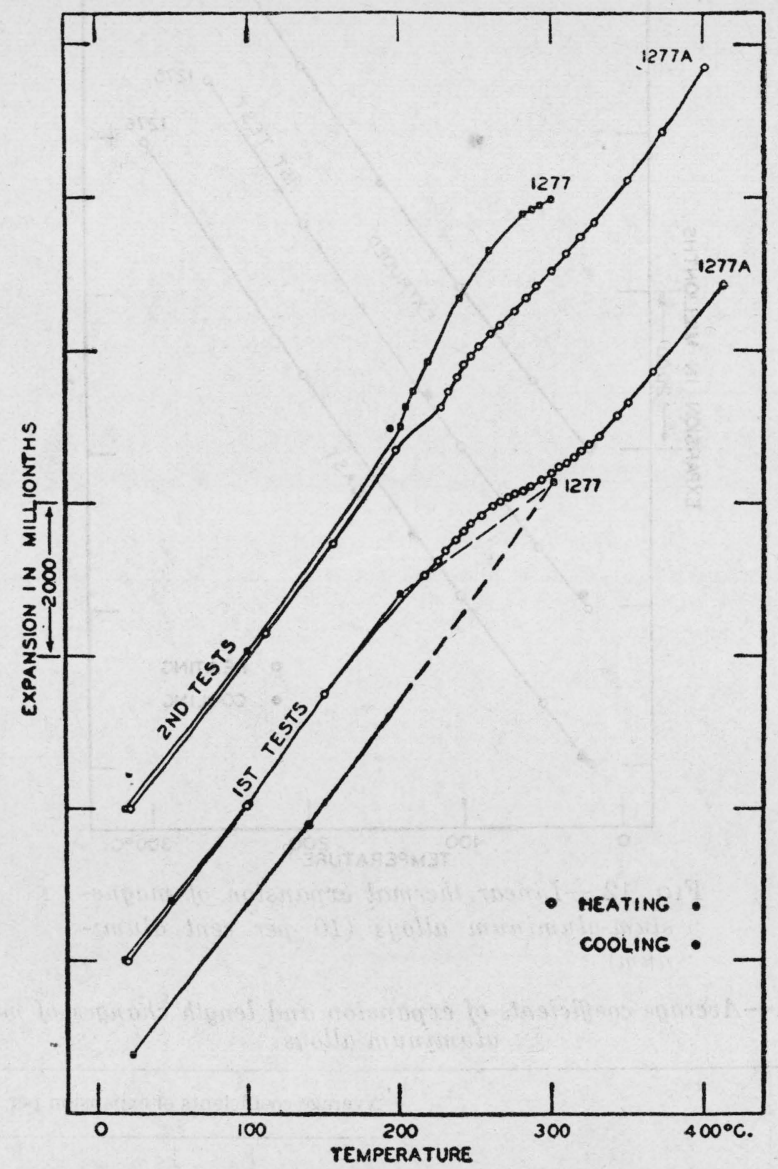

Fig. 13.-Linear thermal expansion of magnesiumaluminum alloys (10 per cent aluminum)

Extruded at $330^{\circ} \mathrm{C}$., held at $425^{\circ} \mathrm{C}$. for 8 hours, quenched and then aged at $175^{\circ} \mathrm{C}$. for 72 hours

It is interesting to note that for the range from $20^{\circ}$ to $300^{\circ} \mathrm{C}$. the coefficients of expansion of these magnesium-aluminum alloys are practically the same as the coefficients of expansion of aluminumcopper alloys ${ }^{6}$ containing from 4 to 12 per cent copper. From the point of view of expansion there is therefore no gain or loss in substituting magnesium-aluminum alloys for aluminum-copper alloys used in pistons.

' Hidnert, B. S. Sci. Paper No. 497 (19, p. 697; 1925). 
Figure 14 shows the relations between the chemical composition (per cent aluminum by weight) of the magnesium-aluminum alloys and the average coefficients of expansion for three temperature ranges. The values for 0 per cent aluminum or 100 per cent magnesium were taken from the previous subsection. This figure also includes data on magnesium-aluminum-manganese alloys, which will be discussed in the following subsection. For any temperature range indicated in the figure, the coefficient of expansion is practically constant for the magnesium-aluminum alloys containing from 0 to 10 per cent aluminum. The curves show, as was noted before, that the coeffi-

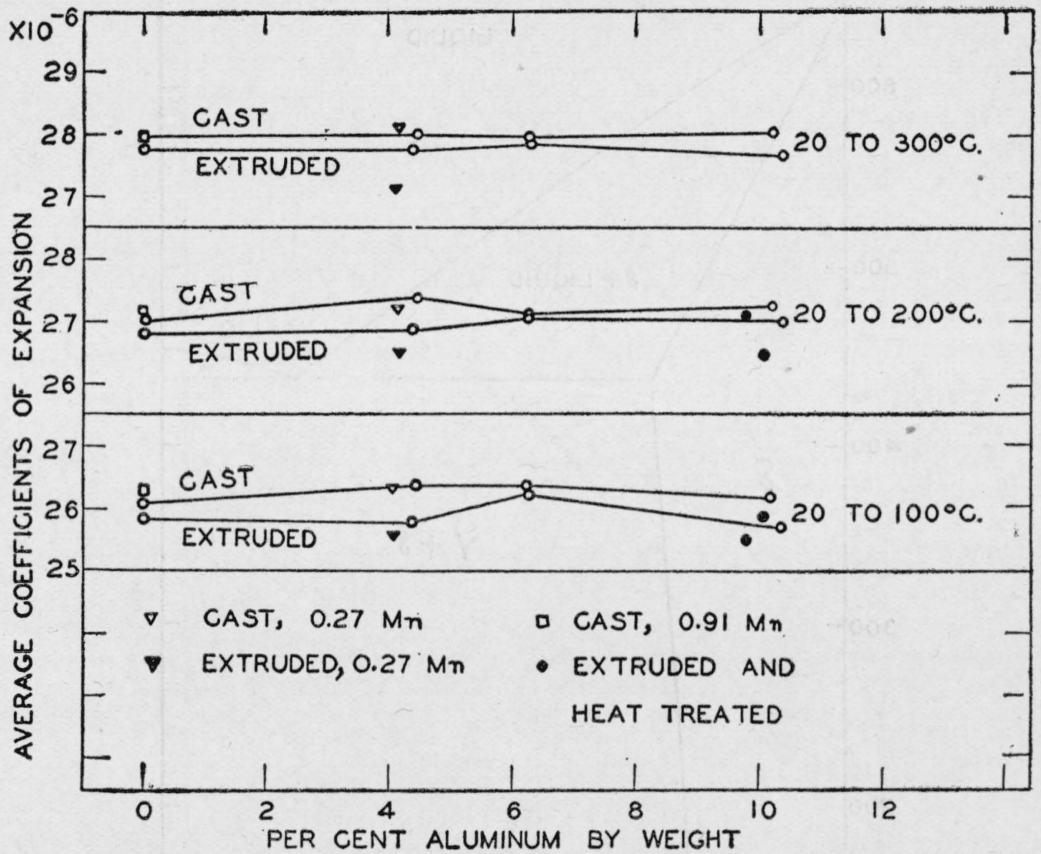

FIG. 14.-Relations between the aluminum content and the coefficients of expansion of magnesium-aluminum alloys, and some effects of small additions of manganese to these alloys

cients of expansion of the extruded magnesium-aluminum alloys are slightly less than the coefficients of the cast alloys.

For a comparison of the constitution of the magnesium-aluminum alloys and the coefficients of expansion the reader should refer to Figures 14 and 15 . The latter figure shows a portion of the magnesium-aluminum equilibrium diagram determined by Hanson and Gayler. ${ }^{7}$ According to the diagram, magnesium retains about 11 per cent aluminum in solid solution at $435^{\circ} \mathrm{C}$. and the solubility decreases slightly as the temperature falls. Experiments ${ }^{8}$ conducted by the Aluminum Co. of America indicate that the solubility de-

7 Hanson and Gayler, J. Inst. of Metals (London), 24 (No. 2), p. 201; 1920.

- Handbook on Magnesium, American Magnesium Corporation. 
creases more rapidly with falling temperature than is indicated by the diagram of Hanson and Gayler. The phase $\delta$ is a solid solution of aluminum in magnesium, and $\gamma$ is the next phase produced by the addition of aluminum to $\delta$. Opportunity for heat treatment by solution quenching and precipitation hardening exists in magesiumaluminum alloys containing about 10 per cent aluminum. (See fig. 13.) The relation between the chemical composition and the

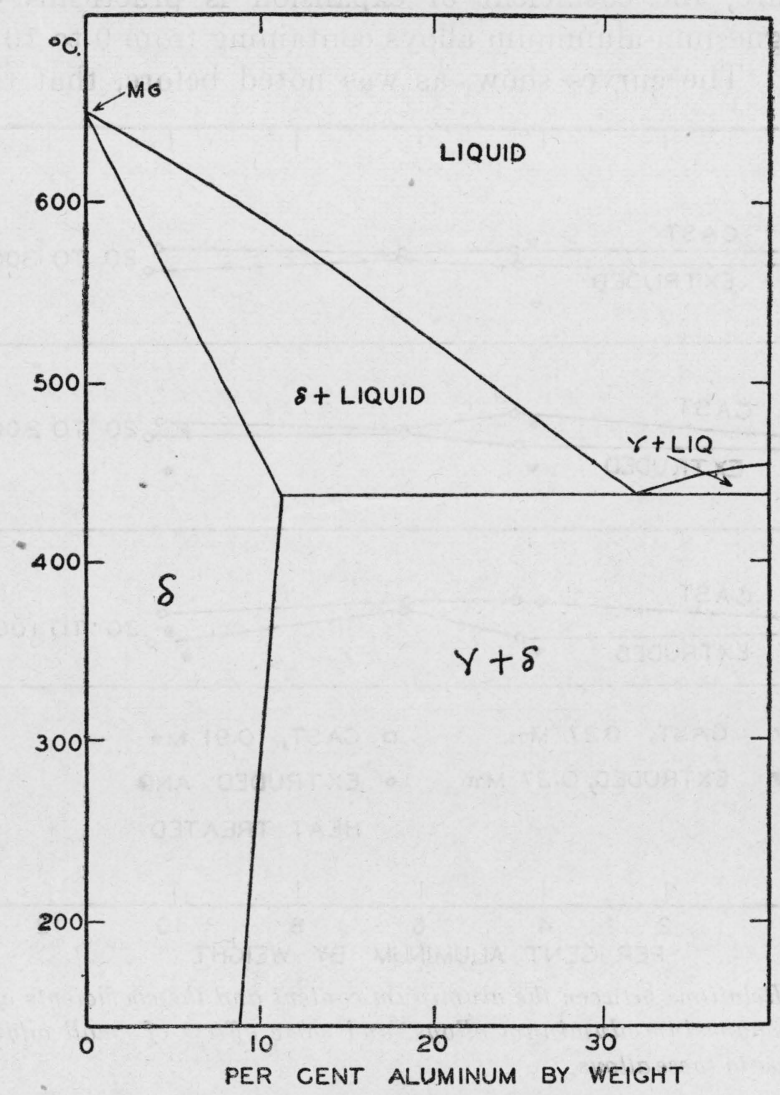

FIG. 15.-Equilibrium diagram of magnesium-aluminum alloys (after Hanson and Gayler)

coefficients of expansion for each temperature range shown in Figure 14 is approximately linear.

\section{MAGNESIUM-ALUMINUM-MANGANESE ALLOYS}

Three samples of magnesium-aluminum-manganese alloys containing less than 1 per cent manganese were investigated by the precision-comparator method (bath) from room temperature to $300^{\circ} \mathrm{C}$. 
Figures 16 and 17 show the observations. The expansion curves of these alloys are regular.

Table 7 gives the average coefficients of expansion which were derived from the expansion curves of the magnesium-aluminummanganese alloys. This table also indicates the differences in length before and after the expansion tests. The minus $(-)$ sign signifies a decrease in length.

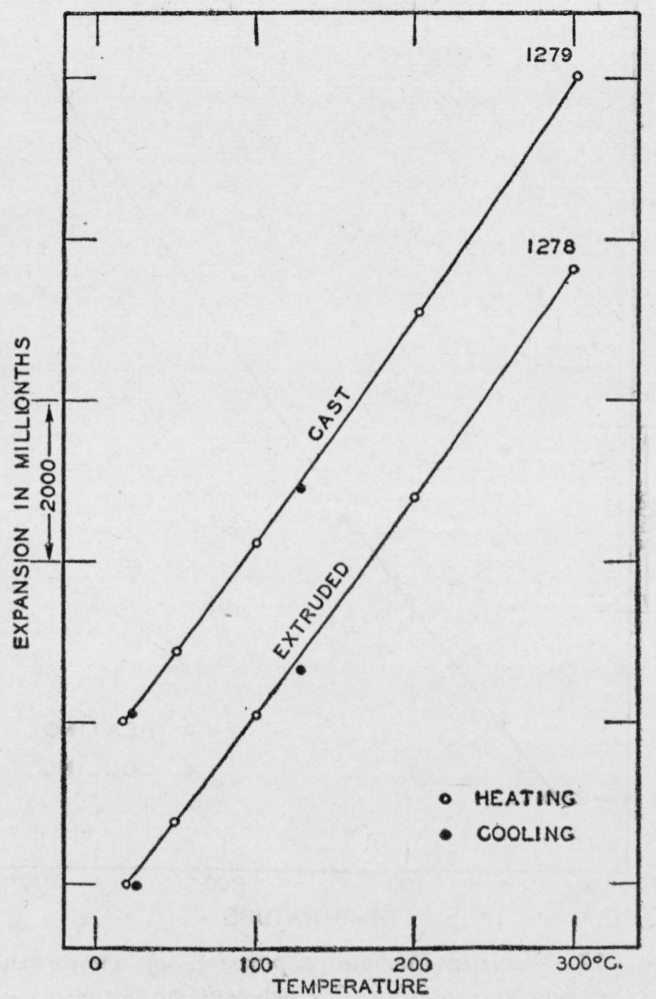

FIG. 16.-Linear thermal expansion of magnesium-aluminum-manganese alloys (4.1 per cent aluminum and 0.3 per cent manganese)

TABLE 7.-Average coefficients of expansion and length changes of magnesiumaluminum-manganese alloys

\begin{tabular}{|c|c|c|c|c|c|c|c|c|}
\hline \multirow{2}{*}{ Sample } & \multicolumn{2}{|c|}{ Content } & \multirow{2}{*}{ Treatment } & \multicolumn{4}{|c|}{$\begin{array}{l}\text { A verage coefficients of expan- } \\
\text { sion per }{ }^{\circ} \mathrm{C} \text {. }\end{array}$} & \multirow{2}{*}{$\begin{array}{l}\text { Change } \\
\text { in length } \\
\text { due to } \\
\text { heat } \\
\text { treat- } \\
\text { ment } \\
\text { received } \\
\text { during } \\
\text { test }\end{array}$} \\
\hline & Alumi- & $\begin{array}{c}\text { Man- } \\
\text { ganese }\end{array}$ & & $\begin{array}{l}20^{\circ} \text { to } \\
50^{\circ} \mathrm{C} .\end{array}$ & $100^{\circ} \mathrm{to}$ & $\begin{aligned} & 20^{\circ} \text { to } \\
& 200^{\circ} \mathrm{C}\end{aligned}$ & $\begin{aligned} & 20^{\circ} \text { to } \\
& 300^{\circ} \mathrm{C}\end{aligned}$ & \\
\hline $\begin{array}{l}1279-\ldots- \\
1278-\ldots . \\
1280\end{array}$ & \begin{tabular}{|c} 
Per cent \\
4.14 \\
4.10 \\
.01
\end{tabular} & $\begin{array}{r}\text { Per cent } \\
0.27 \\
.27 \\
.91\end{array}$ & $\begin{array}{l}\text { Cast in vacuum furnace at } 690^{\circ} \mathrm{C} \text { - } \\
\text { Extruded at } 390^{\circ} \mathrm{C} \\
\text { Cast at } 670^{\circ} \mathrm{C}\end{array}$ & $\begin{array}{r}\times 10^{-6} \\
26.1 \\
24.9 \\
26.0\end{array}$ & $\begin{array}{r}\times 10^{-6} \\
26.6 \\
25.6 \\
26.3\end{array}$ & $\begin{array}{r}\times 10^{-6} \\
27.3 \\
26.4 \\
27.2\end{array}$ & $\begin{array}{r}\times 10^{-6} \\
28.1 \\
27.2 \\
27.9\end{array}$ & $\begin{array}{r}\text { Per cent } \\
-0.01 \\
-.02 \\
-.01\end{array}$ \\
\hline
\end{tabular}


The coefficients of expansion of the magnesium-aluminummanganese alloys increase with temperature. The coefficients of the extruded alloy containing about 4 per cent aluminum and 0.3 per cent manganese are less than the coefficients of the corresponding cast alloy. The greatest deviation in the coefficients shown in the table is $1.2 \times 10^{-6}$.

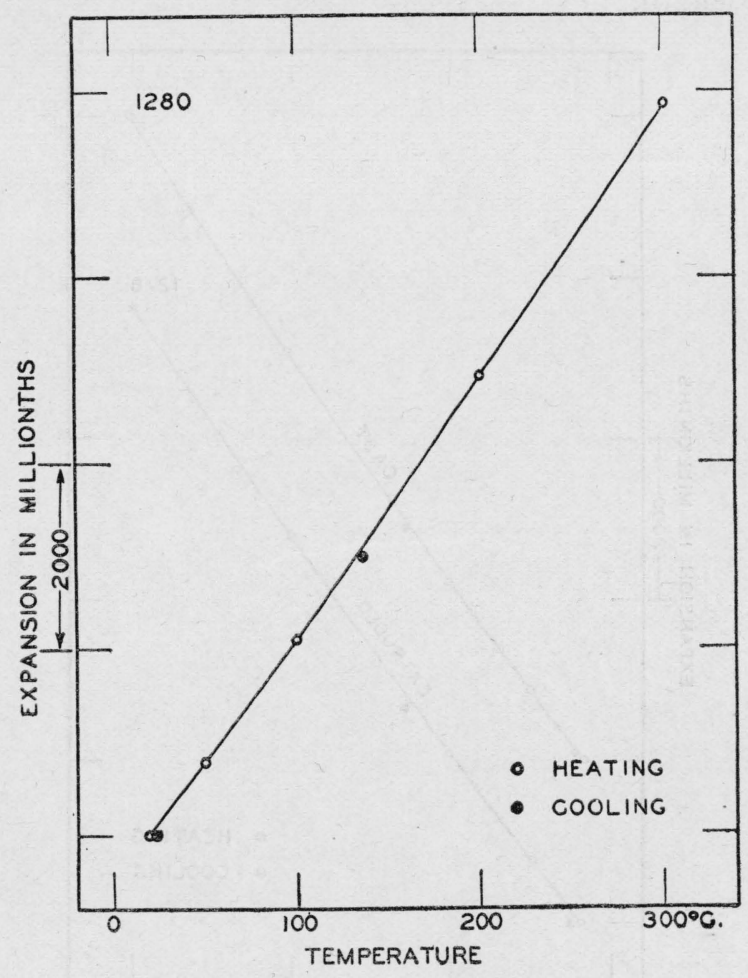

FIG. 17.-Linear thermal expansion of magnesiummanganese alloy ( 0.9 per cent manganese)

Data on the magnesium-aluminum-manganese alloys are shown in Figure 14 of the preceding subsection. The addition of 0.9 per cent manganese to magnesium caused a slight increase in the coefficients of expansion. The coefficients of the extruded ternary alloy containing about 4 per cent aluminum and 0.3 per cent manganese are less than the binary magnesium-aluminum alloys (cast and extruded) containing the same amount of aluminum. 


\section{SUMMARY}

This paper gives data on the linear thermal expansion of 6 samples of cast and extruded magnesium and 11 samples of cast and extruded magnesium alloys (magnesium-aluminum and magnesium-aluminummanganese alloys). The samples of magnesium were investigated over various temperature ranges between $-183^{\circ}$ and $+500^{\circ} \mathrm{C}$. and most of the alloys between room temperature and $300^{\circ} \mathrm{C}$. The previous history (preparation, treatment, chemical composition, etc.) of the specimens is included. The expansion curves of the samples are shown and discussed.

Three types of expansion apparatus were used in this research, and a summary of available data by previous observers on the thermal expansion of magnesium and some magnesium alloys is given.

The following equations are given as the most probable seconddegree equations for the expansion of cast magnesium and extruded magnesium between room temperature and $500^{\circ} \mathrm{C}$.

Cast magnesium:

Extruded magnesium:

$$
L_{\mathrm{t}}=L_{\mathrm{o}}\left[1+\left(24.94 t+0.00946 t^{2}\right) 10^{-6}\right]
$$

$$
L_{\mathrm{t}}=L_{\mathrm{o}}\left[1+\left(24.66 t+0.00976 t^{2}\right) 10^{-6}\right]
$$

Average of equations (1) and (2):

$$
L_{\mathrm{t}}=L_{\mathrm{o}}\left[1+\left(24.80 t+0.00961 t^{2}\right) 10^{-6}\right]
$$

The coefficients of expansion of extruded magnesium are slightly less than those for cast magnesium. This fact also applies for the alloys investigated. Figure 9 shows a comparison of the average expansion curve (equation (3)) obtained in the present investigation on magnesium, with data from previous observers. The values of nearly all observers show good agreement.

Figure 14 shows the relations between the chemical composition of the magnesium-aluminum alloys and the average coefficients of expansion for three temperature ranges. The addition of 0 to 10 per cent aluminum to magnesium causes practically no change in the coefficients of expansion. The expansion curves of the magnesium-aluminum alloy (10 per cent aluminum) which was extruded and heat treated show critical regions above $200^{\circ} \mathrm{C}$. Small additions of manganese ( 0.9 and 0.3 per cent) to magnesium and magnesiumaluminum alloys caused slight changes in the coefficients of expansion.

A comparison of the average coefficients of expansion of the materials investigated are given for several temperature ranges in the following table. For detailed data the reader should refer to the proper sections of the paper. 
TABLE 8.-Average coefficients of expansion of magnesium and magnesium alloys

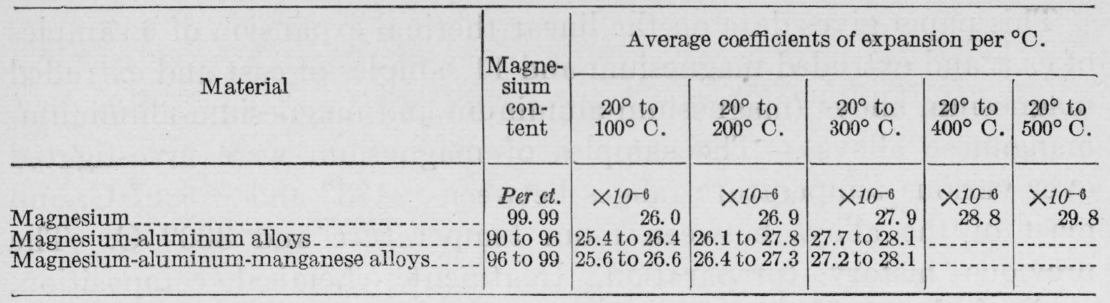

WASHington, July 17, 1928. 